\title{
Development and the Environment: Overview of the Development Planning Process in Agricultural Sector, in Uganda
}

\author{
Andrew Waaswa ${ }^{1} \&$ Felix Satognon ${ }^{2,3}$ \\ ${ }^{1}$ Department of Agricultural Education and Extension, Egerton University, Kenya \\ ${ }^{2}$ Department of Crops, Horticulture, and Soils, Egerton University, Kenya \\ ${ }^{3}$ Laboratory of Genetics, Horticulture and Seed Sciences, University of Abomey-Calavi, Benin \\ Correspondence: Andrew Waaswa, Department of Agricultural Education and Extension, Egerton University, P.O \\ Box 536 Egerton, Kenya. Tel: 256-7-8775-9695. E-mail: waaswa22@gmail.com
}

Received: March 15, 2020

Accepted: July 10, $2020 \quad$ Online Published: October 12, 2020

doi:10.5539/jsd.v13n6p1

URL: https://doi.org/10.5539/jsd.v13n6p1

\begin{abstract}
The social component of the environment associated mostly with human activities has significantly imposed a threat to the only life-support systems of the earth. Uganda made adjustments in its planning process to prioritize environment conservation. However, in the recent past years, mostly between 2013 and 2017, the country stretched its resources to increase agricultural production, both livestock and crops. The objective of this study was to establish and document the development and the environment conservation strategies at global and regional levels with an overview on the development planning process in agricultural sector, in Uganda. The results showed that the sustainable development plans with participatory approach at international, regional, national and local or community levels are the best methods to cope with and reduce the negative impacts of man's activities on the environment. The understanding of the complexes of the environment is very important to ensure the relationship between the social, economic and environmental protection for a sustainable development. The results also indicated that in Uganda, the agriculture industry made consistent efforts to increase agricultural production by 431,161 hectares and livestock heads by 7,878,000 (cattle, sheep, goats, pigs, and poultry) between 2013 and 2017. This increased agricultural greenhouse gas emission due to the use of synthetic fertilizers, burning of the cleared grasses, and use of manures applied to boost soil fertility and the reduction in the trees that sequester $\mathrm{CO} 2$. This study recommended that the agricultural sector should opt for sustainable agriculture by adopting practices like use of multipurpose crops that can offer environmental services like binding soil particles together to control erosion as well as yielding more food products. Dual-purpose livestock breeds should be adopted to avoid immense numbers that serve different purposes that will probably lead to increased GHG emissions.
\end{abstract}

Keywords: methane, carbon dioxide, climate-smart agriculture, nitrous oxide, environment, development, climate change

\section{Introduction}

The growing population has increased human activities with a significant effect on the environment. The planet and its population are facing a potential crisis of environmental destruction by man. Man's activities over many centuries have transformed the natural environment to the point where the whole world is in danger. As the scale of man's intervention in nature amplifies, the scope of nature's repercussions has increased (United Nations Environment Program (UNEP), 2013). The consequences of human activities in pursuit of development on the environment are retaliating with unbearable strokes that manifest as floods and storms, which induce other miserable outcomes like reduction in biodiversity, decline in crop yields and death of animals. This leaves man, the sole cause of the "dance" terrorized and defenseless (Intergovernmental Panel on Climate Change (IPCC), 2012; McBean, 2011). Unsustainable human development activities aggregate the impacts of climate change on food production systems with effects on the economic aspects like increase in food prices positioning producers, all actors in the value chain, and decision-makers in a state of constant reflection on what the solution should be (Porter et al., 2019). This majorly stems from environmental trends that have come to host terrible situations in the world such as deforestation, loss of genetic diversity resources, desertification, pollution of groundwater, toxic air emissions, toxic waste, the rise of the world's sea levels and acidification of the environment (UNEP, 2013). If no action is taken to address these issues, in the coming years, physical and economic losses will increase 
dramatically and the effects, primarily on environmental health, will threaten the ability of nations, enterprises, and communities to thrive sustainably (The UN Special Representative of the Secretary-General for Disaster Risk Reduction (UNISDR), 2013). Unplanned urban development with continuous environmental degradation will multiply these catastrophes (McBean, 2011).

The development planning process of most developing countries gives fewer priorities to the sustainable use of natural resources like land, water resources, and air (United Nations, 2008). This continues to align these countries in positions where they are hit harder by the effects of climate variability (Pramova, Locatelli, Brockhaus, \& Fohlmeister, 2012). Yet, the associated risks of environmental degradation could be addressed through national planning processes that foster wise use of environmental resources (McBean, 2011). Anomalies that disrupt environmental support systems can be stopped, and conditions can be reversed through the implementation of national laws, environmental planning strategies, and regulations based on rational use of natural resources (Liao, Amar, Tagaris, \& Russell, 2012). Many developing countries in Africa like Comoros, Central African Republic, Djibouti, Eritrea, Gambia, Lao PDR, Maldives, Tanzania, Tuvalu, and Uganda are given a higher ranking of the endowment of their natural resources (Pramova et al., 2012). The environment will continue supporting the development and other human-related activities if countries adopt national adaptation strategies by integrating the sustainable use of environmental resources into their planning processes (Liao et al., 2012; Moffatt \& Kohler, 2008).

Uganda, like any other environment-dependent country, made adjustments in its planning process to prioritize environment conservation (Ministry of Water and Environment (MWE), 2015). Efforts to mostly increase agricultural production, the country's mother sector has come to consider conservation measures like fallowing, use of organic fertilizers, and afforestation (National Environment Management Authority (NEMA), 2007). This relinquishes the resources that would be used to restore the damage caused on the environment in case conservation measures are ignored (NEMA, 2017). However, between 2013 and 2017, the Ugandan government stretched its resources to increase agricultural production, both livestock and crops to meet food demands and increase the country's Gross domestic product (GDP) through the exportation of the excess produce (Food and Agriculture Organization (FAO), 2017). Effects on the environment that emanate from the agricultural development continue increasing. This is due to ineffective and inappropriate application of conservation measures at global and regional levels because of non-reconnaissance of the set strategies. At the national level, the extent to which agriculture developed and its effects on greenhouse gas emissions needed to be documented. This study, therefore, aimed at establishing and documenting the development and the environment conservation strategies at global and regional levels with an overview on the development planning process in agricultural sector, in Uganda. Specifically, it documented the agricultural sector development in Uganda that emerged between 2013 and 2017 and its contribution to $\mathrm{GHG}\left(\mathrm{CO}_{2}, \mathrm{~N}_{2} \mathrm{O}\right.$, and $\left.\mathrm{CH}_{4}\right)$ emission. It recommended sustainable measures that can be integrated in the development planning processes for environmental sustainability.

\section{Materials and Methods}

This study employed a monographic method, and the literature reviewed ranged from journal articles, books, book chapters to web pages. These were studied purposely to document development and planning processes, consideration for environment and sustainable development. The literature included both published and unpublished sources for example government and organization reports, and it ranged from 2003 to 2019. Analysis of the quantitative data was done using Microsoft Excel.

\section{Results and Discussion}

\subsection{Understanding of the Environment}

By its nature, the environment encompasses the political, legal, and human-made boundaries (European Commission \& Directorate-General Communication, 2014). It can also be defined as: "All that which is external to the human host. Can be divided into physical, biological, social, cultural, etc., any or all of which can influence the health status of populations". This definition suggests that the environment includes anything that is not genetic However, it can be argued that even genes are influenced by the environment in the short or long-term (Benetti, 2007). It can be considered to be the built or natural surroundings. The built environment may require being understood as a complex social-ecological system where multiple-related metabolisms interact at different levels. From this broad understanding, the dividing line on what is considered as natural and what is considered as-built environment becomes subjective and it changes with the historical context. Over time, notions of environmental interpretation and material conceptualization have enlarged from year-to-year, economic, and biological exchanges to energy, material, financial, and information flows extended through time and space (Moffatt \& Kohler, 2008). The life-supporting systems of the biosphere are endangered, and some species of value forced into extinction due 
to massive deforestation, destruction of habitats, overuse of energy resources, and environmental pollution (Ramachandra \& Nagarathna, 2005). The understanding of this complexity, need to be understood by man.

\subsection{Development and Environment}

Development cannot occur without both bearable and unbearable outcomes caused to the environment. However, different concepts are attributed to development over time (Katsoulakos, Misthos, Doulos, \& Kotsios, 2016). Economists define development as an intended cause related to an increase in the production of products and services within an economy. They use the gross domestic product as a measure of development, which they define as; a total measure of production equal to the sum of the gross values added of all residents, institutions engaged in production including any taxes, and minus subsidies, on products not included in the value of their outputs (Organisation for Economic Co-operation and Development (OECD) Statistics, 2002). According to Katsoulakos et al. (2016), there is a positive relationship between development and economic growth because the later produces significant interactions between development and both natural and man-made environments. Development manifests with both advantages and disadvantages on the environment; the disadvantages are accountable for the increased environmental pollution and the ridiculous use of environmental resources (Katsoulakos et al., 2016; Liao et al., 2012; McBean, 2011). This drove leaders of the world to adopt a new development paradigm, focused not only on the economy but also that incorporates the social and the environmental aspects for a sustainable development (Figure 1). Sustainable development was introduced as a continental priority in the Earth Summit, in Rio de Janeiro, in 1992 (UNEP, 2013). Followed by outcomes of 2002 and 2012, where most of the world's countries re-vowed to achieve sustainability. Sustainable development was operationalized to have three pillars: economic development, social development, and environmental protection (Katsoulakos et al., 2016). Environmentalists advocate for sustainability as the best approach in dealing with all the man's activities. The widely used definition of sustainable development is stated by National Audit Office of Estonia \& University of Tartu (2019) as the development that meets today's demands without jeopardizing the future generations' ability to meet their demands. Sustainable development can only be realized by maintaining a balance between the environment, social and economic aspects. To achieve this balance, social development must be bearable in the environment, economic development should be environmentally viable and there must an equitable social and economic development (Figure 1).

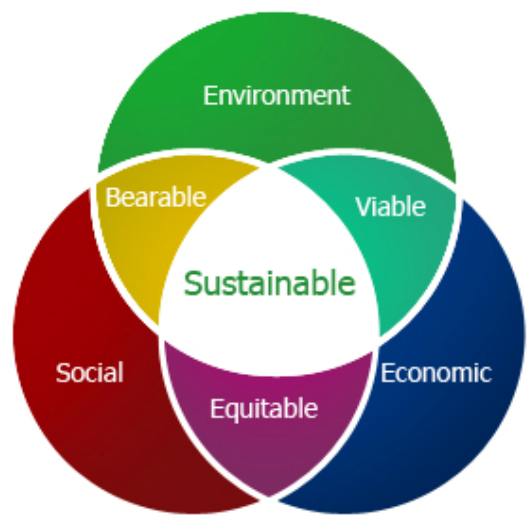

Figure 1. Relationships between environmental, social and economic pillars of sustainable development (National Audit Office of Estonia \& University of Tartu, 2019)

\subsection{Planning Process}

According to Homeland Security (2012), a plan is considered to be an established group of endeavors that are expected to achieve goals. Planning is taken at three broad stages and these are: 1) Strategic planning which establishes the setting of goals and the expected direction to be taken at the next stage of planning; 2) Operational planning, this is the second stage of planning that lays down the activities and means for executing the plan; 3 ) Tactical planning, this illustrates ways for executing the means to accomplish the operational activities in a stipulated period. For effectiveness, the three planning levels should be done with the entire community. These guide the planners in developing an awareness of the strengths, weaknesses, opportunities and threats, to help them in coming up with plans and the planning outcomes that base on mission, objectives, and stakeholders' interests.

For effectiveness and realization of the set goals, the nations and communities need to think of the useful tools, 
that the community needs for support, and to develop extensive plans that cater for everyone with active actor involvement (Gustafsson \& Andréen, 2018). The planning processes should be conducted based on identified gaps and should follow the steps in figure 2 (Homeland Security, 2012).

\begin{tabular}{|c|c|c|c|c|c|}
\hline $\begin{array}{l}\text { STEP 1 } \\
\text { Form a } \\
\text { Collaborative } \\
\text { Planning Team }\end{array}$ & $\begin{array}{l}\text { STEP } 2 \\
\text { Understand } \\
\text { the Situation }\end{array}$ & $\begin{array}{l}\text { STEP } 3 \\
\text { Determine } \\
\text { Goals \& } \\
\text { Objectives }\end{array}$ & $\begin{array}{l}\text { STEP 4 } \\
\text { Plan } \\
\text { Development }\end{array}$ & $\begin{array}{l}\text { STEP } 5 \\
\text { Plan Preparation, } \\
\text { Review, \& } \\
\text { Approval }\end{array}$ & $\begin{array}{l}\text { STEP } 6 \\
\text { Plan } \\
\text { Implementation } \\
\text { \& Maintenance }\end{array}$ \\
\hline
\end{tabular}

Figure 2. Planning process (Homeland Security, 2012)

\subsection{International Suggested Development and Environmental Planning Strategies}

According to United Nations (2008), world leaders tackled issues related to environmental degradation and UNISDR called upon nations to include sustainable development measures in their development plans. In the report presented to the United Nations Economic and Social Council in the view of sustainable development, UNISDR (2005) purported several principles, which include:

1) the incorporation of the economic, socio and environmental pillars of sustainable development into national planning and policymaking is challenging but should be done;

2) the scope and nature of sustainable development initiatives pose challenges to governments, due to this, the civil societies, local leaders, private entities and the entire public should participate in the implementation of the sustainable development plans;

3) climate change poses lifetime challenges on humans and, if not attended to, it may impede realization of the sustainable development;

4) satisfactory efforts should be directed towards combating environmental degradation, this could partly address climate change, plus alleviation of poverty and contribute to economic development;

5) dedication is needed to foster acceptance and unbiased diffusion of efficient, renewable and affordable energy systems and emerging technologies; and

6) World leaders and concerned bodies called for collective action to use philanthropic support in minimizing environmental degradation risks and vulnerabilities. Emphasis should be given to risk reducing and mitigating measures during national planning process of different countries and communities (UNISDR, 2005)

\subsection{Suggested Development and Environmental Planning Strategies by African Bodies}

The New Partnership for Africa's Development (NEPAD), 2003) in its strategy for implementation of initiatives that conserve the environment, integrated sustainability in its development plans and activities. It sought to foster the sustainable use of natural resources in Africa and to establish political and public support at both regional and local levels. It also sought to support and remind African nations of their regional and global commitments under the environmental conventions and any legal regularities that they are part. It promised to offer support in improving the institutional framework for regional environmental governance through participatory planning processes. The African Union and commission recognized the problems caused to environmental resources in execution of development activities. As a remedy, it drafted a program on climate action which African countries were called to implement (African Union Commission, 2015). The call statement reads: "Act with a sense of urgency on climate change and the environment" and that the following should be done:

1) five regional technology centers should be identified to link with the selected climate technology bodies at national levels;

2) establish climate change programs that target the youths and women;

3) identify and scale out resilient agricultural programs like Conservation Agriculture Adaptation Programs (CAADP);

4) foster and implement forest management programs sustainably;

5) put in place national adaptation plans, systems and structures for example, the national designated authorities and implementation entities that conserve the environment; and

6) diversity in Africa should be sustainably exploited and managed for the gain of her people 


\subsection{Agricultural Sector Development and Environmental Planning Strategies in Uganda}

Unlike other sectors, the agricultural sector's productivity is directly affected by changes in the environment. The environmental variability is experienced in form of prolonged dry spells, reduced water levels in rivers and lakes, sediment accumulation in dams, uncontrolled flooding, pollution arising from chemicals, decline in biodiversity, soil erosion and reduced soil fertility (FAO, 2017; Ministry of Agriculture, Animal Industry and Fisheries (MAAIF), 2016; UNEP, 2006; World Bank, 2008). To solve these challenges and plan for the sector development, the MAAIF established climate change unit that works with MWE to implement activities planned by the Uganda Climate Smart Agriculture (CSA) initiative. In addition, MAAIF (2016) suggested that efforts seeking to increase agricultural production for a sustainable development should:

1) increase agricultural production through CSA practices and gender sensitive approaches

2) enhance the resilience of cultivation landscapes and societies to the effects of climate change

3) transform agricultural sector and practices to increase its contribution to minimal carbon development pathways

4) effectively and efficiently scale up CSA by creating a supportive environment

5) increase collaborations and resource pooling measures to support execution of CSA via corporations with existing initiatives like funds that target the upscaling of climate conservation operations.

6) initiate technical support provision to all stakeholders including farmers and civil societies on how to design and implement climate change interventions in the agriculture sector at all levels.

\subsection{Effects of Agricultural Development on the Environment and GHG Emission}

Efforts to increase agricultural production lead to emission of greenhouse gases (FAO, 2019). The main environmental problems caused by increased agricultural production fall into two groups: increase in $\mathrm{GHGs}\left(\mathrm{CO}_{2}\right.$, $\mathrm{N}_{2} \mathrm{O}$ ) due to deforestation and crop production activities and accumulation of salt deposits and nitrate fertilizer remnants mostly on irrigated lands (Norse, 2003). It is estimated that the global food system contributes one quarter to one third of total global GHGs emissions (Heidecke, Montgomery, Stalb, \& Wollenberg, 2018). According to OECD (2016), agriculture alone adds a noticeable percentage of the GHGs emissions which contribute to climate change. Agricultural activities directly contribute to $17 \%$ while 7 to $14 \%$ is due to changes in the use of land. Therefore, it is part of the problem and the major and direct agricultural GHG are $\mathrm{CO}_{2}, \mathrm{~N}_{2} \mathrm{O}$ emissions from soils, fertilizers, manure and urine from grazing animals; and $\mathrm{CH} 4$ produced by ruminant animals and from paddy rice farming. These gases have a significant contribution to global warming (Norse, 2003; Rojas-Downing, Nejadhashemi, Harrigan, \& Woznicki, 2017). The agricultural sector development that occurred between 2013 and 2017 in Uganda also contributed to the GHG emission. 


\subsubsection{Agricultural Sector Development in Uganda That Occurred between 2013 and 2017}

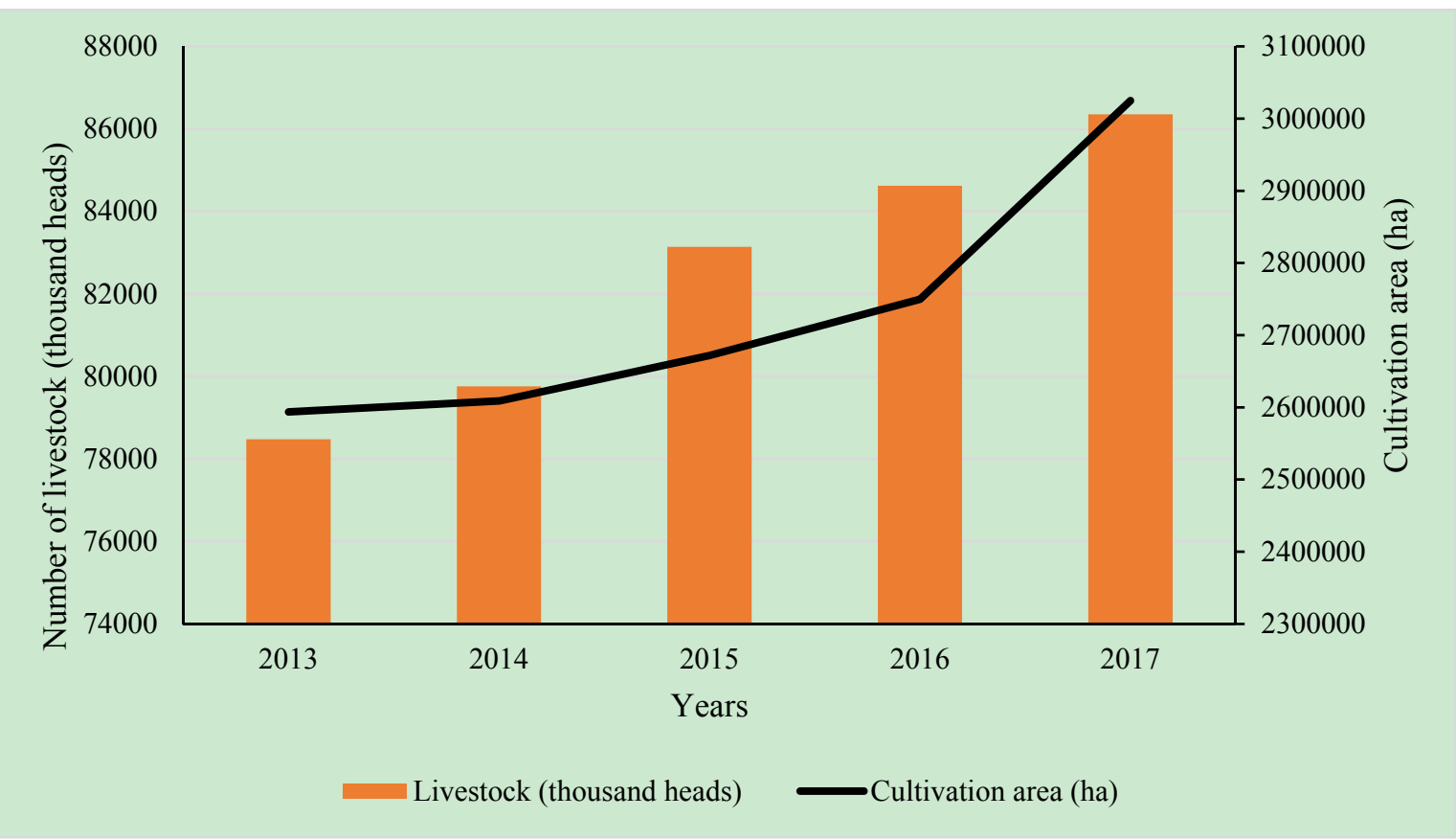

Figure 2. Agricultural sector development in Uganda that occurred between 2013 and 2017

Source: (FAOSTAT, 2017; Uganda Bureau of Statistics (UBOS), 2019)

Livestock heads that were estimated at 78,477,000 by 2013 exponentially increased between 2013 and 2017 by $7,878,000$. This was due to the increase in number of cattle, sheep, goats, pigs, and poultry heads. This is in line with the study by Nabarro \& Wannous (2014) that indicated that for any country to meet the food demands for its population has to adjust its agricultural production to sustain food and nutrition security. Thus calling for an increase in livestock production and its products as protein sources. On the other hand, farming land consistently increased by 431,161 hectares between 2013 and 2017. This happened at the expense of the forests and grassland that were cleared. According to FAO (2016), an increase in agriculture farming space leads to the use of many reserved natural resources like forests, grasslands, and marginal places like swamps to harness crop yields. Decisions to open more farming space lead to loss and to endangering many valuable species whose habitats get destroyed during the process (Ewing, Kostyack, National Wildlife Federation, Smart Growth America (Organization), \& NatureServe (Program), 2005). Also, the process leads to emissions of GHG (Figure 5) due to use of synthetic fertilizers, burning of the cleared grasses, use of manures applied to boost soil fertility and the reduction in the trees that sequester $\mathrm{CO}_{2}$ (World Bank, 2016). 


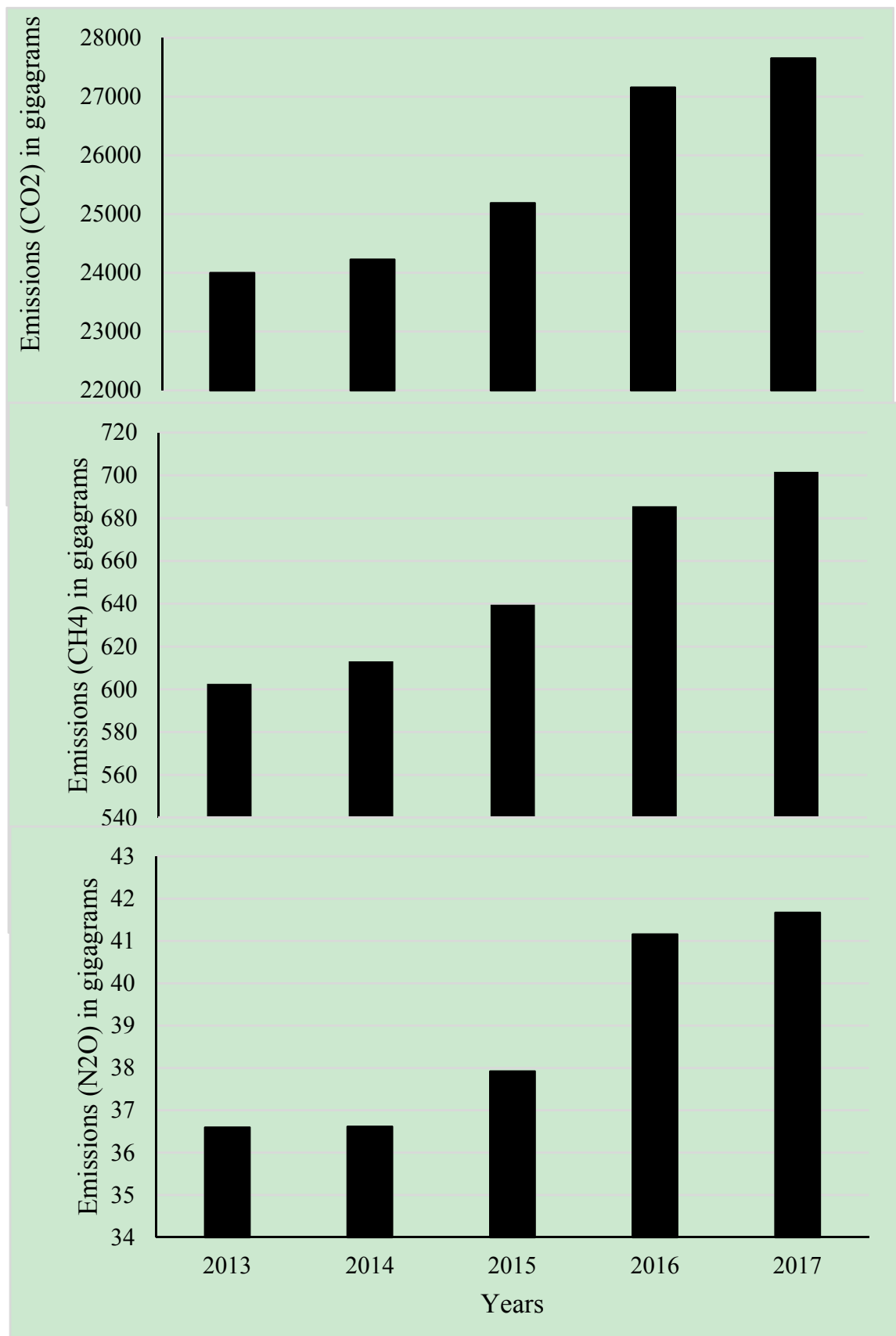

Figure 3. $\mathrm{GHG}\left(\mathrm{CO}_{2}, \mathrm{CH}_{4}\right.$ and $\left.\mathrm{N}_{2} \mathrm{O}\right)$ emission from agriculture development between 2013 and 2017 in Uganda (FAOSTAT, 2017)

Increased agricultural production of both livestock numbers and cultivation area to a less extent contributed to an increase in GHG emissions. The GHG emissions $\left(\mathrm{CO}_{2}, \mathrm{CH}_{4}\right.$ and $\left.\mathrm{N}_{2} \mathrm{O}\right)$ in Uganda significantly increased between 2013 and 2017. The $\mathrm{CO}_{2}$ emission from agriculture greatly contributed to the GHG emissions followed by $\mathrm{CH}_{4}$ emission. The $\mathrm{CH}_{4}$ and $\mathrm{N}_{2} \mathrm{O}$ were mainly released from the enteric fermentation process of livestock and manures. The trend in GHG seen in figure 5 is in line with findings by FAO (2013), which state that the increase in livestock heads increases GHG that are emitted from manure decomposition and enteric fermentation processes.

\section{Conclusions and Recommendations}

Man's activities over many centuries have transformed the natural environment to the point where the whole world is in danger. Sustainable development that is achieved by a strong interaction between social, environmental and economic aspects has been seen as the best approach to solve these challenges without affecting the future 
generations' capabilities to meet their needs. To achieve sustainable development, the nations and communities need to adopt a participatory approach in the planning processes by developing tools that consider the environment yet responding to the needs of everyone. Efforts to increase agricultural production should follow the development plans whose objectives encompass lowering the emission of greenhouse gases. The agricultural sector should opt for sustainable agriculture by adopting practices like use of multipurpose crops that can offer environmental services like binding soil particles together to control erosion as well as yielding more food products. Marginal places such as swamps should not be encroached on in the process of increasing farming space as they offer habitats to aquatic species, which may die on losing their habitat. Dual-purpose livestock breeds should be adopted to avoid immense numbers that serve different purposes that will probably lead to increased GHG emissions. Finally, climate-smart agriculture practices that lead to increased agricultural production, at the same time offering environmental services, should be incorporated in the sector's development strategies.

\section{Acknowledgment}

The authors acknowledged the MSc. Scholarship (MasterCard@RUFORUM Scholarship) by MasterCard Foundation (MCF) through Regional Universities Forum for Capacity Building in Agriculture (RUFORUM) that made this study possible.

\section{References}

African Union Commission. (2015). Agenda 2063: The Africa we want. Addis Ababa, Ethiopia: African Union Commission.

Benetti, A. D. (2007). Preventing disease through healthy environments: Towards an estimate of the environmental burden of disease. Engenharia Sanitaria e Ambiental, 12(2), 115-116. https://doi.org/10.1590/S141341522007000200001

European Commission, \& Directorate-General Communication. (2014). Environment: A healthy and sustainable environment for present and future generations: [updated in November 2014]. Retrieved from http://dx.publications.europa.eu/10.2775/90841

Ewing, R. H., Kostyack, J., National Wildlife Federation, Smart Growth America (Organization), \& NatureServe (Program). (2005). Endangered by sprawl: How runaway development threatens America's wildlife. Washington, D.C.: National Wildlife Federation: Smart Growth America : NatureServe.

Food and Agriculture Organization of the United Nations. (2013). In P. J. Gerber, B. Henderson, \& H. P. S. Makkar (Eds.), Mitigation of greenhouse gas emissions in livestock production: A review of technical options for non$\mathrm{CO}_{2}$ emissions. Rome: Food and Agriculture Organization of the United Nations.

Food and Agriculture Organization of the United Nations. (2016). State of the world's forests: Forests and agriculture: Land-use challenges and opportunities. Rome: FAO.

Food and Agriculture Organization of the United Nations. (2017). The state of food and agriculture: Leveraging food systems for inclusive rural transformation. Rome: Food and Agriculture Organization of the United Nations.

FAOSTAT. (2017). FAOSTAT- data. Retrieved November 30, 2019, from http://www.fao.org/faostat/en/\#data/GT

Food and Agriculture Organization of the United Nations. (2019). Agriculture and climate change: Challenges and opportunities at the global and local level: collaboration on climate-smart agriculture. Rome, Italy: Food and Agriculture Organization of the United Nations.

Gustafsson, S., \& Andréen, V. (2018). Local Spatial Planning Processes and Integration of Sustainability Perspective Through a Broad Systems Perspective and Systematic Approach. In W. Leal Filho (Ed.), Handbook of Sustainability Science and Research (pp. 567-580). https://doi.org/10.1007/978-3-319-630076_35

Heidecke, C., Montgomery, H., Stalb, H., \& Wollenberg, L. (Eds.). (2018). International Conference on Agricultural GHG Emissions and Food Security - Connecting research to policy and practice -. In International Conference on Agricultural GHG Emissions and Food Security (p. 163). Berlin, Germany: Thünen Working Paper 103.

Homeland Security. (2012). National Planning System. 10. Retrieved from https://www.fema.gov/media-librarydata/1454504745569-c5234d4556a00eb7b86342c869531ea0/National_Planning_System_20151029.pdf

Intergovernmental Panel on Climate Change (IPCC). (2012). In C. B. Field, V. Barros, T. F. Stocker, Q. Dahe, D. J. Dokken, K. L. Ebi, ... P. M. Midgley (Eds.), Managing the Risks of Extreme Events and Disasters to 
Advance Climate Change Adaptation: Special Report of the Intergovernmental Panel on Climate Change Cambridge (pp. 582). UK and New York (N.Y), USA: Cambridge University Press and N.Y.

Katsoulakos, N. M., Misthos, L.-M. N., Doulos, I. G., \& Kotsios, V. S. (2016). Environment and Development. In Environment and Development (pp. 499-569). https://doi.org/10.1016/B978-0-444-62733-9.00008-3

Liao, K.-J., Amar, P., Tagaris, E., \& Russell, A. G. (2012). Development of risk-based air quality management strategies under impacts of climate change. Journal of the Air \& Waste Management Association, 62(5), 557 565. https://doi.org/10.1080/10962247.2012.662928

McBean, G. (2011). Environment and Water for Life - In Canada and Around the World. Global Bioethics, 24(14), 109-116. https://doi.org/10.1080/11287462.2011.10800709

Ministry of Agriculture, Animal Industry and Fisheries (MAAIF). (2016). Agriculture Sector Strategic Plan 2015/16-2019/20 "Draft." Kampala, Uganda: Ministry of Agriculture, Animal Industry and Fisheries (MAAIF).

Ministry of Water and Environment (MWE). (2015). Water and Environment Sector Development Plan 2015/162019/20. Kampala, Uganda: Ministry of Water and Environment.

Moffatt, S., \& Kohler, N. (2008). Conceptualizing the built environment as a social-ecological system. Building Research \& Information, 36(3), 248-268. https://doi.org/10.1080/09613210801928131

Nabarro, D., \& Wannous, C. (2014). The potential contribution of livestock to food and nutrition security: The application of the One Health approach in livestock policy and practice. Revue Scientifique et Technique de l'OIE, 33(2), 475-485. https://doi.org/10.20506/rst.33.2.2292

National Audit Office of Estonia, \& University of Tartu. (2019). 1.1. Sustainable development. Retrieved July 3 , 2020, from Introduction to environmental auditing in public sector website: https://sisu.ut.ee/envintro/book/1-1-sustainable-development

National Environment Management Authority (NEMA). (2007). State of Environment Report for Uganda. Kampala: NEMA, Uganda.

National Environment Management Authority (NEMA). (2017). Albertine Graben environmental baseline monitoring report 2015. Kampala, Uganda: National Environment Management Authority (NEMA).

New Partnership for Africa's Development (NEPAD). (2003). New Partnership for Africa's Development (NEPAD) Action Plan for the Environment Innitaitive. Midrand, South Africa: New Partnership for Africa's Development (NEPAD).

Norse, D. (2003). Agriculture and the environment: Changing pressures, solutions and trade-offs. In J. Bruinsma (Ed.), World Agriculture: Towards 2015/2030: An FAO Perspective (pp. 331-371). London: Earthscan Publications Ltd.

OECD. (2016). Agriculture and Climate Change: Towards Sustainable, Productive and Climate-Friendly Agricultural Systems (OECD Meeting of Agriculture Ministers: Background Note No. 70). https://doi.org/10.1787/5jxrclljnbxq-en

OECD Statistics. (2002). OECD Glossary of Statistical Terms-Gross domestic product (GDP) Definition. Retrieved November 30, 2019, from https://stats.oecd.org/glossary/detail.asp?ID=1163

Porter, J. R., Challinor, A. J., Henriksen, C. B., Howden, S. M., Martre, P., \& Smith, P. (2019). Invited review: Intergovernmental Panel on Climate Change, agriculture, and food-A case of shifting cultivation and history. Global Change Biology, 25(8), 2518-2529. https://doi.org/10.1111/gcb.14700

Pramova, E., Locatelli, B., Brockhaus, M., \& Fohlmeister, S. (2012). Ecosystem services in the National Adaptation Programmes of Action. Climate Policy, 12(4), 393-409. https://doi.org/10.1080/14693062.2011.647848

Ramachandra, T. V., \& Nagarathna, A. (2005). Understanding Environment. Current Science, 89.

Rojas-Downing, M. M., Nejadhashemi, A. P., Harrigan, T., \& Woznicki, S. A. (2017). Climate change and livestock: Impacts, adaptation, and mitigation. Climate Risk Management, 16, 145-163. https://doi.org/10.1016/j.crm.2017.02.001

The UN Special Representative of the Secretary - General for Disaster Risk Reduction (UNISDR). (2013). Proposed Elements for Consideration in the Post - 2015 Framework for Disaster Risk Reduction. Presented at the Geneva, Switzerland. Geneva, Switzerland: The UN Special Representative of the Secretary - General 
for Disaster Risk Reduction (UNISDR).

Uganda Bureau of Statistics (UBOS). (2019). Explore Statistics - Page 2 - Uganda Bureau of Statistics. Retrieved July 3, 2020, from https://www.ubos.org/explore-statistics/2/

UNEP. (2006). In E. O. Odada, D. O. Olago, \& W. O. Ochola (Eds.), Environment for Development: An Ecosystems Assessment of Lake Victoria Basin Environmental and Socio-economic Status, Trends and Human Vulnerabilities. Nairobi, Kenya: United Nations Environment Program (UNEP) and Pan African START Secretariat (PASS).

UNISDR. (2005). Hyogo Framework for Action 2005-2015: Building the Resilience of Nations and Communities to Disasters. Presented at the Kobe, Hyogo, Japan. Kobe, Hyogo, Japan: International Strategy for Disaster Reduction.

United Nations. (2008). Achieving sustainable development and promoting development cooperation: Dialogues at the Economic and Social Council. New York: United Nations.

United Nations Environment Program. (2013). In M. K. Tolba \& A. K. Biswas (Eds.), Earth and Us: Population - Resources - Environment - Development. Oxford, London: Butterwort-Heinemann Ltd.

World Bank. (2008). World Development Report 2008: Making agricultural systems more environmentally sustainable. Washington, DC: The World Bank.

World Bank. (2016). Greenhouse gas mitigation opportunities in agricultural landscapes: A practitioner's guide to agricultural and land resources management [Agriculture global practice]. Washington, DC: The World Bank.

\section{Copyrights}

Copyright for this article is retained by the author (s), with first publication rights granted to the journal.

This is an open-access article distributed under the terms and conditions of the Creative Commons Attribution license (http://creativecommons.org/licenses/by/4.0/). 